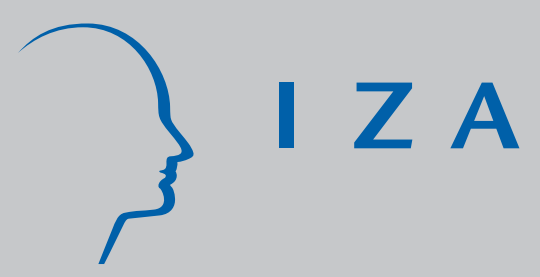

IZA DP No. 3564

Selection Criteria and the Skill Composition of Immigrants: A Comparative Analysis of Australian and U.S. Employment Immigration

Guillermina J asso

Mark R. Rosenzweig

J une 2008 


\title{
Selection Criteria and the Skill Composition of Immigrants: A Comparative Analysis of Australian and U.S. Employment Immigration
}

\author{
Guillermina Jasso \\ New York University \\ and IZA
}

Mark R. Rosenzweig

Yale University

Discussion Paper No. 3564

June 2008

IZA

P.O. Box 7240

53072 Bonn

Germany

Phone: +49-228-3894-0

Fax: +49-228-3894-180

E-mail: iza@iza.org

Any opinions expressed here are those of the author(s) and not those of IZA. Research published in this series may include views on policy, but the institute itself takes no institutional policy positions.

The Institute for the Study of Labor (IZA) in Bonn is a local and virtual international research center and a place of communication between science, politics and business. IZA is an independent nonprofit organization supported by Deutsche Post World Net. The center is associated with the University of Bonn and offers a stimulating research environment through its international network, workshops and conferences, data service, project support, research visits and doctoral program. IZA engages in (i) original and internationally competitive research in all fields of labor economics, (ii) development of policy concepts, and (iii) dissemination of research results and concepts to the interested public.

IZA Discussion Papers often represent preliminary work and are circulated to encourage discussion. Citation of such a paper should account for its provisional character. A revised version may be available directly from the author. 


\section{ABSTRACT}

\section{Selection Criteria and the Skill Composition of Immigrants: A Comparative Analysis of Australian and U.S. Employment Immigration*}

This paper uses survey data on employment immigrants in Australia and the United States to identify the main determinants of the size and skill composition of employment immigrants to developed countries. Our approach emphasizes the key roles of world prices of skills and country proximity. Our empirical results are consistent with the view that these factors, rather than the nuances of selection systems, dominate. There are five main findings: (1) Higher skill prices in sending countries decrease the number of immigrants but increase their average schooling. (2) More-distant countries send fewer but more skilled immigrants. (3) Given skill prices and proximity, countries with higher income send more immigrants, of lower skill. (4) Within a sending country, Australia attracts less total but higher-skill migrants than does the United States. This can be attributed, however, to the fact that the skill price in Australia is lower than the U.S. skill price, so that immigration gains are greater from immigrating to United States. (5) The estimated coefficients determining migration flows to Australia and the United States are the same for both countries. We conclude that geography thus matters in the sense that who a country's neighbors are, in terms of their level and type of development, has a significant effect on the size and skill composition of employment migrants. There is no evidence that the differences in the selection mechanism used to screen employment migrants in the two countries play a significant role in affecting the characteristics of skill migration.

JEL Classification: F22, J31, J61, J68, O15

Keywords: immigration policy, immigrant selection criteria, skill prices, country proximity, employment immigration, highly skilled immigration, globalization

Corresponding author:

Guillermina Jasso

Department of Sociology

New York University

295 Lafayette Street, $4^{\text {th }}$ Floor

New York, NY 10012-9605

USA

E-mail: gj1@nyu.edu

\footnotetext{
* Authors are listed in alphabetical order. The New Immigrant Survey research was supported by the National Institutes of Health (NICHD and NIA) under grant HD33843, with partial support from the U.S. Citizenship and Immigration Services, the National Science Foundation, the Assistant Secretary for Planning and Evaluation (DHHS), and the Pew Charitable Trusts. An earlier version was presented at the Conference on Skilled Migration Today: Prospects, Problems and Policies, sponsored by the Columbia University Program on Immigration Economics, the Russell Sage Foundation, and the Council on Foreign Relations. We are grateful to participants for many useful comments; and we thank the anonymous reviewers and editors for their close reading and valuable comments. We also gratefully acknowledge the intellectual and financial support of New York University and Yale University. This paper is forthcoming in: Jagdish Bhagwati and Gordon H. Hanson (eds.), Skilled Migration Today: Phenomenon, Prospects, Problems, Policies. New York: Oxford.
} 
Many developed countries of the world are contemplating expanding the inflow of skilled migrants. The most recent reforms of immigration systems in Australia and the United States, for example, shifted from promoting family reunification to enlarging the flows of employment or skilled migrants -- migrants selected on the basis of job skills. Information is scarce, however, on how the design of employment-based immigration selection mechanisms affects the composition of skilled immigrants or on the determinants of skilled migration flows in general.

There are two literatures assessing the determinants of the skill-composition of immigrants based on national statistics on immigrants or the foreign-born. The largest looks at immigration flows from the perspective of the potential migrant seeking to maximize utility, and relates observed flows of the migrants to home-country conditions (e.g., Borjas, 1987). This literature, however, chiefly because of data limitations, cannot distinguish between immigrants admitted via employment criteria and those coming through other channels, including by marriage, through kinship, or without any legal basis for immigration. Given that a large portion of flows to developed countries with significant immigration are via marriage, for example, this work is not very useful for assessing the consequences of enlarging the scope for skill or employment-based immigration. ${ }^{1}$ This literature also lacks a coherent and implementable method for evaluating how sending country conditions affect immigration flows. ${ }^{2}$

A second, small, literature looks at the different immigration systems of developed countries and attempts to assess their effects on the composition of immigration flows. A recent example is a comparison of the Canadian and Australian immigration systems (Richardson and Lester, 2004). This study was made possible by the recent availability of survey data on immigrants for the two countries that contains information on visas -- the channels by which immigrants entered. The study, however, pays little attention to the decisions by immigrants

\footnotetext{
${ }^{1}$ The most recent surveys of legal immigrants to Australia and the United States indicate that 45 and 34 percent, respectively, of adult immigrants immigrated by marrying a receiving-country citizen.

${ }^{2}$ Borjas' (1987) study is empirically unsuccessful in identifying immigrant self-selection based on the model used. See also Jasso and Rosenzweig (1990b)
} 
themselves, and thus ignores the literature emphasizing the self-selection of immigrants and the influence of sending country conditions. The fact that Canada and Australia have very different country neighbors, for example, is not discussed. It is unlikely that even if Canada and Australia had the same selection systems they would experience the same inflows of immigrants. The fundamental problem is that there are essentially two observations in the study -- one for Canada and one for Australia -- and many differing characteristics of their selection systems, domestic labor market conditions, and neighbor characteristics. Identification of immigration system effects therefore seems unlikely if immigrant self-selection is taken into account.

In this paper we look at employment-based immigration flows to Australia and the United States using data from the first round of the most recent Australian survey of legal immigrants, the second cohort of the Longitudinal Survey of Immigrants to Australia (LSIA2), and the first round of the U.S. New Immigrant Survey (NIS) 2003 cohort, merged with sending-country characteristics. The survey data sets provide information on visa class thus permitting the identification of those immigrants screened on the basis of employment skills. The hypothesis we test is that sending-country conditions and thus immigrant self-selection on the basis of economic gain dominate in determining the skill composition of employment immigrants. To carry this out we develop an empirically tractable framework for examining the determinants of immigration flows for employment immigrants. We emphasize that key determinants of the size and skill composition of immigrant flows are how skills are priced in different countries and proximity. Thus, who a receiving country's neighbors are matters substantially more than tweaks to selection mechanisms.

Many have argued over the relative merits of an immigrant selection system based on points awarded for selected immigrant characteristics, such as in Australia and Canada, versus the U.S. system of preferences (e.g. Martin, 2004). This argument has essentially taken place without any evidence. Moreover, closer inspection of the Australian and U.S. systems for choosing employment-based immigrants suggests that there is not a fundamental difference between them. Both award visas on the basis of petitions by domestic employers for workers in 
particular occupations and both are attentive in part to schooling (as will be seen below, some applicants can self-petition). The Australian system attempts through the point system to fine tune the flow somewhat, paying somewhat more attention to schooling and using a schooling floor. $^{3}$

In part 1 of the paper we review briefly the current selection systems for employment and skill-based immigration in Australian and the United States, showing the that they contain the same essential elements, but with some differences in screening. Section 2 describes the Australian and U.S. data on new immigrants and presents descriptive statistics on the schooling distributions of employment immigrants in the two countries based on the survey data. These show that the average schooling of Australian employment immigrants is higher than that of U.S. employment immigrants. However, the same is also true for marital immigrants in the two countries. And, there is little evidence that even the English language requirements for employment immigrants in Australia and the absence of such a requirement in the U.S. system matter in terms of the observed initial English capabilities of the immigrants. These facts suggest that factors affecting immigrant self-selection are at play. In part 3 of the paper we develop the framework of immigrant self-selection with focus on the private gains from migration for agents with differing skills based on differences in the prices of skill across countries and differing migration costs. We then show how country-specific skill prices can be identified with existing data to implement the model. Section 4 contains the econometric estimation of world skill prices based on data from the NIS Pilot survey on the home-country wages of U.S. immigrants combined with home-country information on aggregate economic characteristics that affect the home-country skill price. In section 5 we use the estimates to show how the skill prices of the different country neighbors of Australia and the United States differ and how the country mix of employment immigrants relative to marital immigrants differ across the two countries with respect to skill price and proximity.

\footnotetext{
${ }^{3}$ The U.S. Select Commission on Immigration and Refugee Policy considered the option of a point system and did not recommend it, as discussed in Jasso (1988).
} 
Part 6 implements the model, estimating the determinants of the size and average schooling level of employment immigration flows to the two countries. There are five principal findings: 1. Higher skill prices in sending countries decrease the number of immigrants but increase their average schooling. 2. More-distant countries send fewer but more skilled immigrants. 3. Given skill prices and proximity, countries with higher income send more immigrants, of lower skill. 4. Within a sending country, Australia attracts less total but higherskill migrants than does the United States. This can be attributed, however, to the fact that the skill price in Australia is lower than the U.S. skill price, so that immigration gains are greater from immigrating to the United States. 5. The estimated coefficients determining migration flows to Australia and the United States are the same for both countries. We conclude that geography thus matters in the sense that who a country's neighbors are, in terms of their level and type of development, has a significant effect on the size and skill composition of employment migrants. There is no evidence that the differences in the selection mechanism used to screen employment migrants in the two countries play a significant role in affecting the characteristics of skill migration.

\section{Employment Immigrant Selection Systems in Australia and United States: A Brief}

\section{Overview}

At first glance, the United States and Australia appear to have very different systems for admitting immigrants based on employment. The United States follows the preference category system, in which employment-based visas are allocated via five preference categories, ranging from "Priority Workers," the first preference, which includes three subcategories (the world-class extraordinary-ability subcategory, a subcategory for outstanding professors and researchers, and a subcategory for multinational executives) to the fifth preference, a category for investors. In all but the fourth and fifth preference categories, filing is by an employer, except for first-preference "aliens with extraordinary ability" and second-preference immigrants with a "national interest" waiver, who may petition for themselves. Australia follows a point system, in which there is a set 
of basic minimal requirements, and points are assigned for characteristics such as age, occupation, and Australian schooling. Every immigrant must meet a points threshold.

Moreover, the two countries appear to differ somewhat in the balance of emphasis between inputs (such as schooling) and outcomes (such as occupational and financial achievement). The U.S. system gives somewhat short shrift to inputs and places great weight on outcomes. For example, eligibility for the top subcategory of the top preference category "aliens with extraordinary ability" -- is established by providing either evidence of a major internationally recognized award or three out of ten kinds of evidence, which include prizes, publications, sitting on panels which judge the work of others, artistic exhibitions, and high salary or commercial success in the arts, and which, significantly, do not include educational credentials (Form I-140). Similarly, the requirements for a second-preference visa based on “exceptional ability in the sciences, arts, or business," while including educational credentials as one of the six types of evidence of which three must be presented (Form I-140), nonetheless explicitly exclude educational credentials for the subset of applicants with "exceptional ability in the sciences or arts" eligible for the blanket Schedule A certification for Group II occupations: "An alien, however, need not have studied at a college or university in order to qualify for the Group II occupation.” (20 CFR, part 656.5, e-CFR retrieved 14 May 2008).

In contrast, the Australian system appears to have a greater regard for inputs, stipulating age (prospective immigrants must be under 45 years of age), schooling (post-secondary education, such as university or trade, is required), and skills assessment (carried out by official authorities). Points are then conferred for particular levels of several characteristics: age, skill, English language, specific work experience, occupation in demand (or job offer), Australian qualifications, intended residence, and spouse skills. Age is negatively rewarded (18-29 years, 30 points; 30-34 years, 25 points; 35-39 years, 20 points; $40-44$ years, 15 points). Skill points are awarded based on a combination of schooling and occupation: 60 points for an occupation with associated specific training (such as a degree or trade certificate), although in some cases experience can substitute for training; 50 points for general professional occupations, combined 
with a bachelor's degree or higher, but one which need not be related to the occupation; and 40 points for a general skilled occupation (to which the requisite diploma or advanced diploma need not be related). There is no mention of achievements as in the U.S. - no publications, professional associations, awards, sitting on panels which judge the work of others, or financial success. Further, extra points are conferred if the intended occupation is in demand (15 points plus an additional 5 points if the prospective immigrant also has a job offer in that occupation); occupations in demand include a mix of highly- and less-skilled occupations, such as obstetricians, welders, hairdressers, furniture upholsterers.

In large degree, however, the systems are similar. Australia has a list of occupations that qualify an immigrant and excludes others, which pertains to all immigrants. The U.S. system for the second- and third-preference categories requires labor certification, which is tantamount to requiring that immigrants have an occupation on an approved list. Although education is not emphasized in the U.S. system, there are categories that qualify persons based on educational qualifications, subject to having an approved occupation. Moreover, the effects of the difference in emphasis on performance and inputs depend on the real-world correlation between inputs and outcomes. If the link between inputs and outcomes is tight, then the two systems may differ in style but not in substance. There are some notable specific differences in the list of approved or desired occupations, however. In Australia, all the major medical specialties are in demand (pathology, surgery, psychiatry, radiology, etc.). In the United States, physicians are not eligible for employment-based visas unless they were already practicing in the U.S. in 1978 or they sign up to practice in an underserved geographic area or a VA facility for a total of five years out of a six-year period (in this case, they are eligible for second-preference visas). Fundamentally, setting aside physicians and perhaps age requirements, outstanding professors and researchers, outstanding athletes and artists, and a variety of skilled professionals - all find their way in both systems. Even those with low levels of schooling can immigrate under each system, in the United States because schooling is not a necessary qualification for all categories, in Australia because exceptions are granted on a variety of grounds. Neither country will likely turn away an 
exceptional cinematographer or stuntperson with a third-grade education.

\section{The LSIA2 and the NIS}

a. Survey frames. The LSIA2 (Wave 1) and the NIS-2003 (Round 1) provide comparable information on a probability sample of new immigrants. ${ }^{4}$ The characteristics of the populations represented mainly reflect in-migration and admission decisions, as they are little affected by emigration selectivity. ${ }^{5}$ Both surveys also sampled from records of new immigrants and then attempted to find and interview the sampled respondents, so that the sources of initial sample attrition are comparable. The LSIA2 sampled approximately $10 \%$ of primary applicants, those whose characteristics determined entry eligibility, aged 15 and over who became new immigrants and who entered Australia in the one-year period September 1999 to August 2000. The adult sample portion of the NIS-2003 sampled $4.3 \%$ of all persons 18 and over who were admitted as permanent resident aliens, including principal applicants, comparable to Australia's "primary" applicants, and accompanying spouses in the 7-month period May through November of 2003. Both surveys oversampled primary- or principal-applicant employment immigrants, the groups that are compared in this analysis.

There are two design differences across the two surveys that should be kept in mind in comparing "new" Australian and U.S. immigrants using the two data sets. First, the LSIA2 sampled only new-arrival immigrants, those who were outside of Australia prior to being admitted, while the NIS sampled all immigrants who attained legal permanent residence, including those who adjusted their status and who were thus already residing in the United

\footnotetext{
${ }^{4}$ For comprehensive overview of the LSIA project, see Hugo (in press). Brief overviews of the NIS project may be found in Jasso (2008) and Jasso, Massey, Rosenzweig, and Smith (2003); for comprehensive overview, see Jasso, Massey, Rosenzweig, and Smith (in press).

${ }^{5}$ Of course, the evaluation of a selection system should be attentive to who among the immigrants stay. This will be possible once the second wave of the NIS-2003 survey is completed. The LSIA2 already has re-surveyed the initial 1999-2000 cohort. Assessments of the skill composition of populations of the foreign born in Census data cannot distinguish between immigration and emigration selectivity.
} 
States. ${ }^{6}$ The NIS permits comparison of adjustees and new arrivals. A second difference in design is that new immigrants who were not residing in Australia during the survey period were not included in the LSIA2. The NIS surveyed new immigrants regardless of their residence (although modified instruments were used for the overseas respondents). In the LSIA2, $15.5 \%$ of surveyeligible immigrants were not interviewed because they were residing outside of Australia at the time of the survey. Finally, as in all surveys, both the LSIA2 and the NIS were unable to interview all sampled respondents. Because the eligible population, based on immigrant records in both surveys, is known, pre-interview loss can be computed accurately for both surveys. For the LSIA2, the loss is $41 \%$, including exclusions based on sample design; for the NIS-2003 it is $31.4 \%{ }^{7}$ Sample size for the LSIA2 is 3124 ; that for the NIS-2003 adults is 8573 .

In this analysis we look at the immigrants selected on the basis of their employment or skill characteristics. These include the primary-applicant "skilled" Australian sponsored immigrants, employer-nominated immigrants and independent immigrants. For the NIS, the comparable group consists of the principal applicants in the employment category preferences, as discussed above. The "skill" immigrant Australian sample size is 832; that for the NIS is 1,369. Because only $29 \%$ of the U.S. employment immigrants were new arrivals, we do not exclude adjustees from the U.S. sample. Adjustee status is likely to directly affect employment status, earnings and English language skill. ${ }^{8}$ Accordingly, we focus our attention on the schooling of the immigrant, which is a more permanent skill characteristic.

\footnotetext{
${ }^{6}$ Many Australian new-arrival immigrants had been to Australia prior to immigrating, but were not already living there immediately before obtaining their immigrant status. Similarly, many new-arrival U.S. immigrants had been to the United States before, and some were in fact already living in the United States, but, for reasons rooted in U.S. immigration law and policy, applying from abroad.

${ }^{7}$ The latter rate is comparable to that of contemporary surveys carried out in developed countries.

${ }^{8}$ Eleven percent of Australian employment immigrants were unemployed at the time of the survey. This relatively high rate of unemployment would also make an analysis of earnings problematical. Interestingly, new arrival employment immigrants in the United States had an unemployment rate of less than $5 \%$. This may reflect the differing labor market conditions in the two countries, the job-offer requirement of U.S. immigration law, or the U.S. residence of new-arrival immigrants. By examining schooling we can ignore the direct effect of domestic labor market conditions.
} 
b. Comparison of the skill distribution of Australian and U.S. skill immigrants. The Australian and U.S. systems for selecting employment or skilled immigrants, as noted, are dissimilar in many ways, with the Australian system in particular appearing to screen more precisely on skill characteristics. The schooling attainment differences across the two skill groups appear to be consistent with this -- average schooling among the Australian skill immigrants is 16.1 years; that for their U.S. counterparts is 15.5 years. Figure 1 provides the distribution of schooling for the two groups based on the categories used in the LSIA2 (and the only available schooling information). As can be seen, although there is a slightly higher proportion of postgraduates among the Australian skill immigrants (38.1\% versus 37.5\%), the major difference between the Australian and U.S. immigrants in the skill category is in the proportion of immigrants with schooling below 12 years. Among Australian skill immigrants, less than 1.5\% did not complete high school, while over $8.2 \%$ of the U.S. employment immigrants did not graduate from high school.

- Figure 1 about here -

There is no question that the availability of skill/employment visas attracts higher-skill immigrants. Figure 2 displays the education distribution for marital immigrants -- those who obtain a visa by marrying a citizen and who are not screened on the basis of skill or employability -- in the Australian and U.S. samples. As can be seen, educational attainment is considerably lower in both countries for marital compared with skill immigrants. Average schooling for marital immigrants in Australia (the United States) is 13.2 (12.9) years, with less than 10\% $(12 \%)$ having post-graduate training and more than $19 \%(26 \%)$ not receiving a high school diploma. It is interesting that there are more lower-schooled U.S. marital and skill immigrants than there are among their Australian counterparts. Given that neither immigration system screens schooling in the marital category, this suggests that immigrant self-selection may also be playing a role in the skill visa category.

- Figure 2 about here -

The operation of self-selection in addition to receiving-country screening is also seen in 
the initial English language ability of immigrants. As noted, the Australian immigration system screens in part based on English language skill in the skill categories. It does not do so for marital immigrants. The U.S. system is inattentive to English skills in both categories. If screening were the only factor determining English language ability, then we would expect to see that Australian and U.S. marital immigrants would have similar abilities in English, while Australian and U.S. skilled immigrants would have very different English language skills. Because English ability is likely affected by duration of residence, to compare English skills across visa groups in the two countries we restrict our attention to new arrivals, excluding the adjustees interviewed in the NIS.

Figure 3 displays the proportions of new-arrival immigrants who reported that they spoke English either not well or not at all stratified by visa and by country. ${ }^{9}$ As expected based on the immigration rules, at entry among Australian immigrants those with skill visas have greater English skills than marital immigrants and a smaller proportion of skill immigrants in Australia had English difficulties compared with those in the United States, who were not screened on this attribute (14.7\% versus 3.1\%). However, marital immigrants also had more difficulty in English compared with employment immigrants among the U.S. immigrants, and the gap is even larger than in Australia between the visa groups. Moreover, the English language skill gap between the U.S. and Australian marital immigrants, neither of whom were screened for English ability, is in the same direction as that between Australian and U.S. skill immigrants and is even larger in terms of percentage points (53.8 versus 39.5$)$. Clearly immigrant self-selection plays a role in the observed language skill composition of immigrants. The questions are whether and how selfselection by immigrants can account for the differing skill distributions of Australian and U.S. employment immigrants and whether a distinct role for the immigrant selection systems of the two receiving countries can be identified

- Figure 3 about here --.

\footnotetext{
${ }^{9}$ The survey questions ascertaining language skill were identical in the two surveys, and are the same as those posed in the U.S. Census.
} 


\section{Skills, Skill Prices and Immigrant Self-Selection}

\section{a. Immigrant decisions, home country characteristics, and immigrant selectivity}

In this section we set out a simple model aimed at highlighting the important factors affecting skill differentials among immigrants due to immigrant self-selection and that can exploit available data. We assume a world economy in which there is a continuum of skills and workers have different levels of skills. Most importantly, rewards to skills (skill prices) differ across countries due to imperfect factor mobility. Skill may also be initially imperfectly transferable across countries.

Each worker i supplies some amount of skill units $x_{i}$. We defer the issue of the measurement of skills until the next section. The worker's wage in home country $j$ is

$$
\mathrm{W}_{\mathrm{ij}}=\omega_{\mathrm{j}} \mathrm{x}_{\mathrm{i}},
$$

where $\omega_{\mathrm{j}}$ is the skill price in country $\mathrm{j}$. Thus, variation in the average wages of workers across countries is due to inter-country differences in both average skill levels and differences in the skill prices.

The initial earnings that worker $i$ could earn in destination country $u$ is given by

$$
\mathrm{W}_{\mathrm{iu}}=\omega_{\mathrm{u}} \mathrm{x}_{\mathrm{i}}^{\delta \mathrm{iu}},
$$

where $\omega_{\mathrm{u}}$ is the destination-country skill price and $\delta_{\mathrm{iu}}, 0 \leq \delta_{\mathrm{iu}} \leq 1$, reflects the initial degree of transferability of a worker i's skills to the destination country's labor market. A worker of given skill earns a different wage in her origin country and initially in the destination country for two reasons: the skill price differs across the two countries and the worker's own skill may not be fully transferable. A worker's skills may be incompletely transferable upon arrival in the destination country due to lack of job contacts, lack of familiarity with the job market or work practices, or poor English skills. With full transferability $\left(\delta_{\mathrm{iu}}=1\right)$, the migrant can initially make use of all of his skill in the destination country; if her skill is initially completely non-transferable across the origin and destination countries $\left(\delta_{\mathrm{iu}}=0\right)$, the migrant enters the destination labor market as if she had the lowest skill level $(\mathrm{x}=1)$.

Given direct costs $C_{j}$ and time costs $\left(1+\pi_{j}\right) W_{i j}$ of migrating from $j$ to $u$, the economic gain 
from migrating from $\mathrm{j}$ to $\mathrm{u}, \mathrm{G}_{\mathrm{ij}}$, for worker $\mathrm{i}$ is

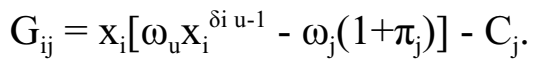

Expression (3) shows that for any level of direct migration costs $C_{j}$ the gains from immigrating, given a positive destination-origin skill price differential net of migration time costs $\left(\omega_{\mathrm{u}}>\omega_{\mathrm{j}}\left(1+\pi_{\mathrm{j}}\right)\right)$, are always higher for more skilled workers and for workers for whom skill transferability is high. ${ }^{10}$

Costs (and benefits) of migration are also psychic. Workers are assumed to (seek to) migrate from country $\mathrm{j}$ to country $\mathrm{u}$ if the utility of residing and working in $\mathrm{u}$ exceeds that from residing and working in $\mathrm{j}$ net of moving costs. The utility of residing in destination-country $\mathrm{u}$ for a worker born in $\mathrm{j}$ is

$$
\mathrm{V}^{\mathrm{u}}=\beta_{1} \Gamma_{\mathrm{iu}}+\beta_{2}\left(\mathrm{~W}_{\mathrm{iu}}-\mathrm{W}_{\mathrm{ij}} \pi_{\mathrm{j}}-\mathrm{C}_{\mathrm{iu}}\right)+\varepsilon_{\mathrm{i}}^{\mathrm{u}},
$$

where $\Gamma_{\text {iu }}$ are amenities from living in $u$ such as a spouse born in $u$ or disamenities associated with a foreign culture and $\varepsilon^{u}$ is a country- and worker-specific error term. The utility of the worker staying in $\mathrm{j}$ is

$$
\mathrm{V}^{\mathrm{j}}=\beta_{1} \Gamma_{\mathrm{ij}}+\beta_{2} \mathrm{~W}_{\mathrm{ij}}+\varepsilon_{\mathrm{i}}^{\mathrm{j}} .
$$

Taking into account the utility gain from migration accounts in part for why, for example, wages in Puerto Rico and the United States are not equalized despite the absence of legal barriers to migration and why migration may occur even if the economic gain $\mathrm{G}$ is negative. ${ }^{11}$

Given the decision rule, migrate iff $\mathrm{V}^{\mathrm{u}}>\mathrm{V}^{\mathrm{j}}$, and expressions (1) through (5) we can show that the skills of immigrant workers in destination countries will differ across their countries of origin given differences in home country skill prices and moving costs. To fix ideas, assume that the marginal distributions of skills in each country are normal (or log normal), the joint stochastic or unmeasured parts of the utility functions (containing the $\varepsilon^{\mathrm{j}}$ ) are independently and identically

\footnotetext{
${ }^{10}$ Chiswick (2000) shows that if higher skill also lowers direct migration costs immigration will be more skill-intensive.

${ }^{11}$ In a more elaborate analysis, the uncertainty in wages may play a role, with potential immigrants maximizing expected utility.
} 
Gumbel distributed, and skills and the $\varepsilon^{j}$ are orthogonal. ${ }^{12}$ The average skill level of immigrant workers then varies with their home-country skill prices according to

$$
\begin{gathered}
\partial \mathrm{E}\left(\mathrm{x}_{\mathrm{i}} \mid \mathrm{V}^{\mathrm{u}}>\mathrm{V}^{\mathrm{j}}\right) / \partial \omega_{\mathrm{j}}= \\
\partial \mathrm{E}\left(\mu_{\mathrm{i}} \mid-\beta_{2} \mathrm{~W}_{\mathrm{iu}}-\beta_{1}\left(\Gamma_{\mathrm{ij}}-\Gamma_{\mathrm{iu}}\right)+\varepsilon^{\mathrm{u}}-\varepsilon^{\mathrm{j}}>-\beta_{2}\left(\mathrm{~W}_{\mathrm{ij}}-\mathrm{C}_{\mathrm{ij}}\right) / \partial \omega_{\mathrm{j}}\right. \\
=\beta_{2} \sigma^{2}\left(\mathrm{x}_{\mathrm{i}}\right) \mathrm{A}>0,
\end{gathered}
$$

where $\mathrm{A}=\lambda^{2}+\beta_{2} \mathrm{~W}_{\mathrm{ij}} \lambda, \lambda=\varphi[\mathrm{H}(\mathrm{P})] / \Phi[\mathrm{H}(\mathrm{P})]$ (the Mills ratio), and $\mathrm{H}()$ is the inverse standard normal cumulative density function evaluated at the probability P that the worker chooses to migrate.

Expression (6) indicates that as long as there is heterogeneity in skills among workers, immigrant workers in a destination country from sending countries with high skill prices will have higher skill levels compared with immigrant workers from low skill-price countries of origin. The intuition is that, from (4), for given fixed monetary and psychic costs of migrating, at low skill price differentials (when $\omega_{\mathrm{j}}$ is high, for given $\omega_{\mathrm{u}}$ ) only the most skilled obtain a net gain from migrating, while when the differential is wide even the least-skilled experience a net gain. ${ }^{13}$ Similarly, across destination countries, those with higher skill prices will attract, from within the same origin countries, more lower-skilled immigrants.

${ }^{12}$ The implications of the model do not depend on these specific distributional assumptions. Such assumptions do permit an empirically tractable analysis of multiple potential destinations, but we have simplified the framework to incorporate one potential destination, given the domination of the United States as an immigrant receiving country.

${ }^{13}$ Implicit in the model is a relationship between inter-country differences in skill prices and the variation in income inequality across countries. In particular, controlling for the distribution of skills, increases in the skill price of a country increases its wage inequality (and average wages). However, it is important to note that our results are not inconsistent with the claim that increased inequality for given mean income in a country can induce more lower-skilled workers to leave (Borjas (1987)). The relationship between the change in a country's income inequality and the skill-selectivity of its migrants will depend on the source of the inequality change. An increase in the origin-country skill price increases incomes for all skill levels of workers but does so proportionally more for the higher-skilled. The gains from migration thus fall for all workers, leading to reduced immigration, but less so for the most skilled. However, while it is not the emphasis in our approach, it is also true that an increase in income inequality brought about, say, by reduced income support for the less-skilled but that also holds median income constant would encourage additional migration of less-skilled workers in our approach. 
Immigrant skills in a destination country will also be positively associated with moving costs:

$$
\partial \mathrm{E}\left(\mathrm{x}_{\mathrm{i}} \mid \mathrm{V}^{\mathrm{u}}>\mathrm{V}^{\mathrm{j}}\right) / \partial \mathrm{C}_{\mathrm{j}}=\left(\omega_{\mathrm{u}} \mathrm{x}_{\mathrm{i}}^{\delta \mathrm{iu}-1}-\omega_{\mathrm{i}}\right) \sigma^{2}\left(\mu_{\mathrm{i}}\right)\left[\lambda^{2}+\beta_{2} \mathrm{C}_{\mathrm{ij}} \lambda\right]>0 .
$$

Again, among those immigrants who incur higher costs of migrating only those with higher skills will obtain a net positive immigration gain, ceteris paribus. Thus, for example, if distance and migration costs are positively associated, among immigrants from countries with the same skill prices, those from countries located farther away will tend to be more skilled and have higher earnings in the destination country. Thus, the skill composition of immigrants across destination countries will vary depending on (i) differences in the characteristics (skill prices) $\omega_{i}$ of the proximate sending countries and (ii) differences in their own skill prices $\omega_{\mathrm{u}}$.

\section{b. The determination and measurement of country-specific skill prices}

The preceding framework makes clear that to evaluate the effects of a destination country's system for selecting immigrants it is necessary to take into account immigrant selfselection. And the latter will depend importantly on the distribution and levels of world skill prices. However, country-specific skill prices are not directly observed, and cannot be inferred from information on country-specific earnings inequality without concomitant information on the distribution of skills. We now discuss a method for estimating country-specific skill prices using available data, thus making it possible to assess immigrant selectivity. Two kinds of data are needed: comparable information on the wages of workers, of given skill, in every country in the world; and country-specific data on aggregate output, numbers of workers, and their average skill levels.

Assume that aggregate output $Y_{j}$ in country $\mathrm{j}$ is produced according to Cobb-Douglas technology

$$
\mathrm{Y}_{\mathrm{j}}=\mathrm{AL}_{\mathrm{j}}^{\alpha} \Pi \mathrm{K}_{\mathrm{nj}}^{\gamma}
$$

where the $\mathrm{K}_{\mathrm{nj}}$ are country j's stock of non-labor resources (e.g., land, capital, minerals) and $\mathrm{L}_{\mathrm{j}}$ is the country's aggregate stock of labor in skill, given by

$$
\mathrm{L}_{\mathrm{j}}=\mathrm{N}_{\mathrm{j}}\left(\mathrm{a}\left(\mathrm{x}_{\mathrm{ij}}\right)\right)
$$


where $\mathrm{N}_{\mathrm{j}}$ is the total number of workers in $\mathrm{j}$ and $\mathrm{a}()$ is an function yielding the average skill units per worker in country $\mathrm{j}$.

The skill price $\omega_{\mathrm{j}}$ is the marginal product of an efficiency unit of labor, given by

$$
\omega_{\mathrm{j}}=\alpha \mathrm{Y}_{\mathrm{j}} / \mathrm{N}_{\mathrm{j}}\left(\mathrm{a}\left(\mathrm{x}_{\mathrm{ij}}\right)\right)
$$

so that

$$
\operatorname{Ln}\left(\omega_{\mathrm{j}}\right)=\operatorname{Ln} \alpha+\operatorname{Ln}\left(\mathrm{Y}_{\mathrm{j}} / \mathrm{N}_{\mathrm{j}}\right)-\operatorname{Ln}\left(\mathrm{a}\left(\mathrm{x}_{\mathrm{ij}}\right)\right) .
$$

Thus, the log of the skill price for any country jis just the log of labor output coefficient (in skill units), plus the $\log$ of output per worker in country $\mathrm{j}$, with a coefficient of 1.0 , minus the $\log$ of country j's average skill per worker. Equation (11) implies that among workers residing in countries with the same output per worker, those workers residing in countries where workers have higher average skill levels are paid lower skill prices, while among workers in countries with the same average worker skill levels, those in countries with higher output per worker receive higher skill prices.

Estimating (11) to obtain country skill prices requires data at the country level. However, although there is information on comparable measures of output per worker for all countries, the transform function $\mathrm{a}\left(\mathrm{x}_{\mathrm{ij}}\right)$ converting measured variables like schooling into aggregate skill units for the economy is not known, and needs to be estimated. Moreover, the dependent variable in (11) is not observed.

Suppose that in addition to aggregate measures of GDP and measures of the determinants of skill we have a random sample of workers from a random sample of countries for whom we observe their local wages, adjusted for comparability across countries based on purchasing parity, and measures of the determinants of their individual skill. In particular, suppose that a worker's level of skill depends on unobservable and observable components, $\mu$ and $\mathrm{S}$ (schooling), respectively, such that

$$
\mathrm{x}_{\mathrm{i}}=\mu_{\mathrm{i}} \exp \left(\beta \mathrm{S}_{\mathrm{i}}\right)
$$

Then the log of worker i's wage in country j, from (1), can be written as

$$
\operatorname{Ln}\left(\mathrm{W}_{\mathrm{ij}}\right)=\operatorname{Ln} \alpha+\operatorname{Ln}\left(\mathrm{Y}_{\mathrm{j}} / \mathrm{N}_{\mathrm{j}}\right)-\operatorname{Ln}\left(\mathrm{a}\left(\mathrm{x}_{\mathrm{ij}}\right)\right)+\beta_{\mathrm{j}} \mathrm{S}_{\mathrm{ij}}+\operatorname{Ln} \mu_{\mathrm{ij}} .
$$


Equation (13) indicates that the measurable log wage for worker $\mathrm{i}$ in country $\mathrm{j}$ is equal to a constant, the observable determinants of log of the country skill price from (12) plus the coefficient on schooling (the schooling return) times worker i's own schooling. The transform function can be estimated from (13), and the implication that the coefficient on the log of GDP per-worker is one can be tested.

The difficulty in using (13) to estimate country-specific skill prices is that there do not exist comparable samples of workers from enough countries -- with the same sample frame and common measures of earnings -- to obtain credible estimates. Suppose, however, we have a sample of workers from different countries who immigrated to a receiving country and who report their earnings in their last job in their home country. Measurement (based on common questions) of wages and worker characteristics will be comparable, with suitable conversion of currencies based on purchasing parity, and many countries will be represented. However, as noted above, immigrants are not randomly (self-) selected from the population of a country's workers. In particular, there will be selection on the unobservable component of skill $\mu$, such that,

$$
\begin{gathered}
\partial \mathrm{E}\left(\mu_{\mathrm{i}} \mid \mathrm{V}^{\mathrm{u}}>\mathrm{V}^{\mathrm{j}}\right) / \partial \omega_{\mathrm{j}}= \\
\partial \mathrm{E}\left(\mu_{\mathrm{i}} \mid-\beta_{2} \mathrm{~W}_{\mathrm{iu}}-\beta_{1}\left(\Gamma_{\mathrm{ij}}-\Gamma_{\mathrm{iu}}\right)+\varepsilon^{\mathrm{u}}-\varepsilon^{\mathrm{j}}>-\beta_{2}\left(\mathrm{~W}_{\mathrm{ij}}-\mathrm{C}_{\mathrm{ij}}\right) / \partial \omega_{\mathrm{j}} .\right.
\end{gathered}
$$

Thus, among workers with the same schooling those workers from high skill-price countries will have higher levels of unmeasured skills (positive selectivity on unobservables). The error term in (13) containing the unobservable component of worker earnings $\mu$ will be correlated with the determinants of the country skill price, leading to biased estimates. For example, (14) implies that due to immigrant selectivity the coefficient on GDP per-worker will be greater than one, biased upwards. To obtain consistent estimates of (13) requires that this selectivity be taken into account.

One remedy is to use the standard selection-correction model (Heckman, 1979). This requires that we estimate the probability that a worker is observed in the sample, which in this case is the probability that a worker in a sending country migrates to the receiving country, 
compute the relevant Mills ratio $\lambda$, for each immigrant, and include it among the regressors in (13). In our model, the probability of sample inclusion (immigration) depends on the determinants of the home-country skill price and factors affecting the costs of migration and the degree of cross-country skill transferability, from (4) and (5). The latter two sets of variables do not affect the home-country skill price, and thus the selection model is well-identified. With information on the home-country wages of a sample of immigrants, the characteristics of the economies and populations from which they came, and measures of moving costs and transferability, the skill price equation (13) can be estimated taking into account selection on unobservables.

\section{Estimating Skill Prices}

a. Data. To estimate the set of world skill prices that potentially affect the magnitude and composition of immigrant flows we use data from the predecessor survey to the NIS-2003, the New Immigrant Survey Pilot (NIS-P), which provides the home-country earnings for a sample of new U.S. legal immigrants, combined with information on the characteristics of immigration sending countries. The sampling frame for the NIS-P consists of the 148,987 persons who were admitted to legal permanent residence during the months of July and August of 1996. Just as for the NIS-2003, the sample of immigrants was drawn from the administrative records of the Immigration and Naturalization Service (INS), which provided information on the immigrants' age, type of visa, and country of origin as well as the address provided by each immigrant to which his or her "green card" (the paper evidence of legal immigration status) was to be sent. The stratified random sample drawn from the records also oversampled migrants with employment visas and undersampled children, and numbers 1,984 persons, of whom 1,839 were adult immigrants. Sample size for adult immigrants is 1032. Details on the survey are given in Jasso et al.(2000).

332 of the sampled immigrants had worked in a foreign country in the ten years prior to the survey and provided earnings data for their last job there. We converted the earnings in the 
last job abroad, provided by the immigrants in native currency units, to dollar amounts based on estimates of the country-specific purchasing power of the currencies from the Penn International Comparisons Project, described in Summers and Heston (1991). These conversion factors are explicitly designed to take into account differences in the "cost of living" across countries and to avoid the distortions associated with exchange rate regimes in order to facilitate cross-country comparisons. The purchasing power parity (PPP) estimates thus permit comparisons of origincountry earnings across U.S. immigrants who have worked in many different countries and are comparable with their U.S. earnings, all denominated in dollars of purchasing power. Based on information on work time and pay periods, to adjust for labor supply differences across workers we converted all pay data to full-time earnings.

We appended to each record information on the characteristics of the immigrant's origin country using information on the last country of residence. To measure skill prices in accordance with the model, we used the real (PPP-converted) GDP per worker estimates from the Penn World Table, Mark 5.6 Summers and Heston, 1991) supplemented with updated 1995 estimates from the ICP. We assume that in the transform function a aggregate worker skills depend on schooling years and schooling quality, and thus we assembled estimates of the average schooling levels of the population aged 25 and over and teacher-student ratios for primary and secondary schools from Barro and Lee (1993). Average schooling estimates are available for a large but not complete subset of countries for which there are PPP GDP estimates. For those countries for which there is no schooling stock estimates we constructed a variable indicating that schooling was missing and set the schooling variable to zero.

We also appended to the micro data country-specific information related to the costs of immigration and transferability. To characterize direct migration costs we obtained the surface distance of every potential origin country's capital to the closest major entry city in the United States. We also obtained information from the PWT 6.1 (Heston et al., 2002) on GDP per adultequivalent, to proxy the resources available to finance migration. As a determinant of skill transferability, we obtained information on whether English was an official language for each 
sending country. Finally, we appended information on the population, in 1990, of the origin countries, representing the potential pool of immigrants. The number of countries for which we have information on at least a subset of these variables is $132 .{ }^{14}$

b. Estimating the probability of sample selection. To account for the selectivity in the sample of immigrants we estimate a blocked probit regression. This is equivalent to estimating a probit for immigration using individual data on samples of 132 of the world's sending-country populations. We use as the population at risk of migration the population of the sending country and the number of U.S. immigrants in the NIS-P sample as the dependent variable. ${ }^{15}$ The number of observations is thus the population of the 132 countries, but because observations within a country are duplicates, the standard errors of coefficients are appropriately corrected.

Table 1 reports the blocked probit coefficients characterizing the decision to immigrate to the United States across 132 countries for two specifications, one including the school quality measures and one without them. In both cases the set of regressors are statistically significant, and the pseudo $\mathrm{R}^{2}$ is respectable, given that a small micro sample of immigrants is being used. The pattern of coefficients for per-worker GDP and aggregate schooling is in conformity with the framework -- in countries with higher output per worker, for given average skill, out-migration is smaller (skill prices are higher), while among countries with the same per-worker output, those with higher levels of schooling send more migrants, because the returns to skill are lower. Higher per-adult GDP, for given skill and per-worker output leads to increased migration, suggesting the importance of resource constraints on migration, although the estimates are not precise. Most

\footnotetext{
${ }^{14}$ The United States shares long land borders with two countries, Canada and Mexico - Canada's southern border extends 3,983 miles, and to the northwest it shares a 1,539-mile border with Alaska; Mexico's northern border spans 1,969 miles. Accordingly, for many natives of Canada and Mexico, the effective distance to the United States is zero. In the multivariate analyses reported below, it makes little difference whether the distance from Canada and Mexico to the United States is measured by zero, a small positive number, the distance form the capital to the closest major port of entry, or a dummy variable.

${ }^{15}$ A more refined analysis would use the population of persons in the age group 25-59, corresponding to the age group of the migrants. This would require accurate information on the population age structure for all countries.
} 
importantly for purposes of identifying selectivity in estimating the skill price equation, distance of the country to the United States importantly deters immigration. And, English language countries, ceteris paribus, send more migrants to the United States.

$$
\text { - Table } 1 \text { about here - }
$$

c. Skill price estimates. Table 2 reports the estimates of the skill price determinants based on the home-country wages of the sample of U.S. immigrants. The first specification omits the Mills-ratio $\lambda$, while the second includes it as a regressor. The sets of country and individual worker characteristics explain $35 \%$ of the total variation in home-country wages among the immigrants and all coefficients but that for the gender variable are statistically significant. The sign patterns for per-worker GDP and for schooling, moreover, conform to the model -- wages are higher for workers of given education and age in countries with greater output per worker, given average country skill levels, and worker wages are lower among countries with the same output per-worker but with higher average schooling levels. These results are also consistent with the migration determinant estimates of Table 1. The point estimate in column one for per-worker GDP is above one, consistent with positive selectivity. And, indeed the coefficient on $\lambda$ in column two is positive. Inclusion of the Mills-ratio moreover lowers the coefficient on per-worker GDP such that the hypothesis that the coefficient is one as indicated by equation (13) cannot be rejected.

- Table 2 about here -

\section{Sending-Country Characteristics of Skill Immigrants in Australia and the United States}

The estimates (column 2) in Table 2 can be used to estimate skill prices for all countries represented in the PWT having information on aggregate schooling. We computed average perworker GDP over the period 1996-2000 for each country and used the most recent Barro-Lee estimates of schooling levels and school inputs. To maximize the number of countries we also used the (unreported) coefficients on the dummy variables indicating absent schooling information included in the skill price regressions to compute skill prices for countries without 
this information. The resulting estimates indicate that the skill price for the United States is $\$ 70.5$ while that for Australia is $\$ 64.9$. Thus, everything else the same, immigrant self-selection should result in immigrants who choose to go to the United States having lower skills than those who go to Australia.

Table 3 reports the estimated skill prices for the top ten countries sending employment immigrants to Australia, based on the LSIA2, and to the United States, based on the NIS-2003. For Australia, the top ten countries account for $75.3 \%$ of all employment migration. Employment immigration is slightly more global for the United States, as the top ten countries account for $70.6 \%$ of all employment immigrants. As can be seen, among the new employment immigrants in Australia, all but one of the top sending countries (Malaysia) has a lower skill price than does Australia, while for the United States, all but two (Canada and Taiwan) have lower skill prices. Table 3 shows that there is considerable overlap in the countries represented by skill migrants in the two receiving countries. However, a Kolmogorov-Smirnov test rejects the hypothesis that the skill immigrants to Australia and the United States have the same country-of-origin distribution. For comparison, Table 4 reports the top-ten country distributions of marital immigrants for the two receiving countries. ${ }^{16}$ The distributions differ more strongly for this group of immigrants across the two receiving countries, suggesting that the marriage market may be less globally integrated than the labor market.

- Tables 3 and 4 about here -

Differences in the selection rules employed by Australia and the United States could explain the differences in the country composition of the skilled migrants coming to the two countries. However, if geography and home-country skill prices matter in determining who chooses to migrate, the United States and Australia face different potential populations of migrants. The first column of Table 5 reports the average distance of a person from Australia and

\footnotetext{
${ }^{16}$ The top ten countries represent $58.6 \%$ and $50.7 \%$ of all marital immigrants in Australia and the United States, respectively. Note that the United States is a significant sending country for Australian marital immigrants, but not vice versa.
} 
from the United States. This is the average of the destination/origin-country distances, weighted by population size. As can be seen, the average person in the world is closer to the United States than he or she is to Australia, by over 1000 miles. Indeed, there are essentially no persons residing within 1000 miles of a major Australian city, but there are 125 million persons residing in countries bordering the United States. If distance raises the cost of migration, this would induce more lower-skill workers to seek to go to the United States than would go to Australia. However, the countries proximate to the two receiving countries also differ in skill prices. We computed the population and distance-weighted average skill price for the two countries (closer distances receive higher weights). Column two of Table 5 reports the average home-country skill price faced by persons proximate to the two countries. The home-country skill price for potential migrants proximate to the United States is higher than that for potential migrants to Australia based on geography and population size. The skill price gain -- the difference between the receiving-country and sending country skill price -- is less dissimilar: $\$ 13$ for Australian potential immigrants and $\$ 9$ for U.S. potential immigrants. Nevertheless, the skill price differences for potential migrants associated with the two receiving countries offset somewhat the effects of differing distances and hence migration costs.

- Table 5 about here --

Columns three and four in Table 5 report the average distances actually traveled by and the average skill prices of the sending countries of the employment immigrants for Australia and the United States, based on the figures reported in Table 3. The average distances of the home countries represented in the flows of migrants in the two countries are more similar to the average distances of their associated potential migrants than they are to those of each other's immigrant flows. And, as expected if gains matter for migration self-selection, the average gain from migration per skill unit for persons who migrate is higher for both countries than the (potential) gain weighted by sending-country populations and distances. The last two columns of Table 5 report the average skill prices and distances of the marital migrants in the two receiving countries. Evidently marital migrants come from countries more proximate to the receiving 
countries and gain less per unit of skill on average compared with employment migrants.

\section{Estimates of Skill Price and Migration Cost Effects on Employment Migration and Skill}

Tables 3-5 hint at the operation of skill prices and migration costs in determining the magnitudes and skill composition of skill immigrants, but it is possible that the composition of migrants just coincidentally reflects the selection rules of the receiving countries rather than systematic choices by persons in sending countries. To more rigorously explore the self-selection of immigrants we use the estimated country skill prices to estimate the determinants of the flow of skill migrants separately for the two receiving countries. We test for whether the estimates conform to the immigrant selection model, in particular whether flows are smaller from sending countries with higher skill prices and at a greater distance, given resource constraints. To do this, we regress for each receiving country the ratio of employment immigrants to population in the sending country on sending-country skill price, distance to the relevant receiving country, GDP per-adult and population size. To make the coefficient estimates comparable and the coefficients interpretable in terms of actual immigrant flows, we use the sampling fractions for the two surveys to blow up the numerator for the Australian and U.S. immigrants by 10 and 39.7, respectively. ${ }^{17}$

Table 6 reports the estimates of the determinants of employment migration flows for both Australia and the United States. The coefficient sign patterns are the same for both receiving countries and conform to the self-selection model -- the fraction of employment immigrants from a sending country is lower the higher the sending-country skill price and the less its proximity to the receiving country. The point estimates for the skill price effects are remarkably similar for the two receiving countries, and indeed only the effects of changes in home-country per-adult GDP appear to differ significantly. Resources appear to matter for the migration of employment immigrants to both countries -- increases in income per adult, given skill prices, increase the

\footnotetext{
${ }^{17}$ The LSIA2 sampled approximately $10 \%$ of new immigrants going to Australia over a 12 -month period. The NIS-2003 sampled 4.3\% of immigrants processed over a seven-month period.
} 
probability of migrating -- and the set of coefficients characterizing the effects of country characteristics on the flows of employment immigrants do not differ significantly across the two receiving countries.

- Table 6 about here --

The results in Table 6, of course, do not imply that the systems of immigrant choice put in place in the receiving countries do not matter. The country variables explain only a small proportion of the immigrant flows. The key issue is whether the variables evidently affecting immigration self-selection explain the variation in the skills of the immigrants, net of receivingcountry attributes. To examine this we estimate the determinants of the average schooling of employment immigrants as a function of the country characteristics that influence immigration. Equation (11) indicates that if there is self-selection, the skill equation, conditional on immigrating, will be the mirror image of the immigration equation -- more skilled immigrants will come from higher skill-price countries, net of distance effects, and from more distant countries, given the skill price. Moreover, to the extent that own income eases migration barriers, net of skill prices and distance, growth in income per-person in a sending country should be associated with an increased flow of lower-skilled immigrants.

In addition to assessing whether immigrant self-selection accounts for any variation in skill composition, we can assess whether all of the differences between the educational attainment of employment immigrants in Australia and the United States, seen in Figure 1, can be explained by immigrant decisions. Unfortunately, because we have cross-sectional data, we cannot identify how variation in receiving country characteristics affects immigrant skill composition. We can only see if net of country characteristics effects there remains an unexplained difference in the educational attainment of Australian and U.S. skill immigrants. However, if there is immigrant self-selection, because the skill price in the United States exceeds that in Australia, net of sending country skill prices and migration costs, immigrant educational attainment in the United States will be lower than in Australia. If we find this, we would be unable to identify any effect of receiving-country selection systems. 
To carry out the analysis, we take the weighted (using sample weights) average of the educational attainment of the employment immigrants in the Australian and U.S. immigrant samples for each sending country and regress that on the same country variables as in the immigration equation. Given that we cannot reject similar immigration behavior for U.S. and Australian employment immigrants, seen in Table 6, we pool both sets of immigrants, with Australian immigrants assigned the Australia-home country distance and U.S. immigrants the U.S.-home country distance. By pooling the samples, we expand the set of country-level observations to 148 , with the Australian immigrants representing 67 countries and the U.S. immigrants representing 81 countries. Theory does not provide any guidance on functional form, so to assess robustness we estimate linear and log-log specifications.

Table 7 reports the estimates of the skill equation selection equations for the two functional forms. The small set of country characteristics explains over a quarter of the variation in educational attainment and over a third of the variation in log educational attainment across employment immigrants in the two countries. More importantly, the pattern of coefficients is consistent with immigrant self-selection, with higher skill prices abroad associated with more educated immigrants and greater proximity leading to less skilled migration. The results also indicate that net of country characteristics, U.S. employment immigrants have about half a year less schooling than Australian immigrants. This is consistent with the United States having a higher skill price than Australia. Thus, we cannot find any evidence of an independent effect of the differing receiving country selection systems, although we cannot rule it out.

- Table 7 about here --

The point estimates suggest that, for example, if the skill price in India were increased to be equal to that of China (a fourfold increase), the average educational attainment of (the fewer) Indian immigrants to Australia and the United States would be $12 \%$ higher. In contrast, increasing sending country incomes fourfold, without raising the returns to skills, would lower the average skill level of (an increased number) of employment immigrants by $7 \%$. Economic development in sending countries thus would affect the skill level of immigrants in developed 
countries, but the way in which development proceeds also appears to matter. Finally, distance matters for skill composition, but not greatly. On average a difference in distance between receiving and sending countries of 1000 miles (the difference between the Australian and U.S. average distances to potential migrants (Table 5)), is associated with a difference in the average educational attainment of employment immigrants of only .1 years (.6\%). Australia's geographic isolation per se evidently accounts for little of the difference between the educational attainment of employment immigrants in the United States and Australia. What matters is the skill wages of Australia's neighbors and those of the United States.

\section{Conclusion}

In this paper we have used new survey data on employment immigrants in Australia and the United States to identify the main determinants of the size and skill composition of employment immigrants to developed countries. In our approach we emphasize the key roles of world prices of skills and country proximity. Our empirical results are consistent with the view that these factors, rather than the nuances of selection systems, dominate. There are five main findings: 1. Higher skill prices in sending countries decrease the number of immigrants but increase their average schooling. 2. More-distant countries send fewer but more skilled immigrants. 3. Given skill prices and proximity, countries with higher income send more immigrants, of lower skill. 4. Within a sending country, Australia attracts less total but higherskill migrants than does the United States. This can be attributed, however, to the fact that the skill price in Australia is lower than the U.S. skill price, so that immigration gains are greater from immigrating to United States. 5. The estimated coefficients determining migration flows to Australia and the United States are the same for both countries. We conclude that geography thus matters in the sense that who a country's neighbors are, in terms of their level and type of development, has a significant effect on the size and skill composition of employment migrants. There is no evidence that the differences in the selection mechanism used to screen employment migrants in the two countries play a significant role in affecting the characteristics of skill 
migration.

These results suggest that as low-income countries increase the rewards provided to skills, developed countries that seek to attract skilled immigrants will experience lower demand for visas by less skilled immigrants. And countries that newly open their borders to employment or skilled-based immigration cannot necessarily use the experience of the United States or Australia to predict the composition and flows of employment immigrants to the extent that the characteristics of their neighboring countries differ substantially. Finally, not all high-skill immigrants arrive with an employment or skill visa. Marriage is a major route to immigration and it is not unlikely that marital migration will increase. Understanding the total world flow of skilled migrants also requires attention to the global marriage market. With new data on the visas of immigrants, new work in this domain may be possible. 


\section{References}

Barro, Robert J., and Jong Wha Lee. 1993. "International Comparisons of Educational Attainment." Journal of Monetary Economics 32:363-94.

Borjas, George J. 1987. "Self-Selection and the Earnings of Immigrants." American Economic Review 77:531-553.

Chiswick, Barry. 1978. "The Effect of Americanization on the Earnings of ForeignBorn Men” Journal of Political Economy 86:897-921.

Chiswick, Barry. 2000. “Are Immigrants Favorably Self-Selected? An Economic Analysis.” Pp. 61-76 in Caroline B. Brettell and James F. Hollifield (eds.), Migration Theory: Talking Across Disciplines, New York, NY: Routledge.

Heston, Alan, Robert Summers, and Bettina Aten, Penn World Table Version 6.1, Center for International Comparisons at the University of Pennsylvania (CICUP), October 2002.

Hugo, Graeme. In press. "The Longitudinal Survey of Immigrants to Australia (LSIA)." Pp. 69-103 in Beverley Morgan and Ben Nicholson (eds.), Immigration Research and Statistics Service Workshop on Longitudinal Surveys and Cross-Cultural Survey Design: Workshop Proceedings. London, UK: Crown Publishing.

Jasso, Guillermina. 1988. "Whom Shall We Welcome? Elite Judgments of the Criteria for the Selection of Immigrants." American Sociological Review 53:919-932.

Jasso, Guillermina. 2008. "New Immigrant Survey.” Pp. 499-500 in William A. Darity Jr. (ed.), International Encyclopedia of the Social Sciences, Second Edition, Volume 5. Detroit: Macmillan Reference USA.

Jasso, Guillermina, Douglas S. Massey, Mark R. Rosenzweig, and James P. Smith. 2000. "The New Immigrant Survey Pilot: Overview and New Findings About Legal Immigrants at Admission." Demography 37:127-138.

Jasso, Guillermina, Douglas S. Massey, Mark R. Rosenzweig, and James P. Smith. 2003. "The New Immigrant Survey in the U.S.: The Experience over Time." www.migrationinformation.org . 
Jasso, Guillermina, Douglas S. Massey, Mark R. Rosenzweig, and James P. Smith. In press. "The U.S. New Immigrant Survey: Overview and Preliminary Results Based on the NewImmigrant Cohorts of 1996 and 2003.” Pp. 29-46 in Beverley Morgan and Ben Nicholson (eds.), Immigration Research and Statistics Service Workshop on Longitudinal Surveys and CrossCultural Survey Design: Workshop Proceedings. London, UK: Crown Publishing.

Jasso, Guillermina, and Mark R. Rosenzweig. 1990a. The New Chosen People:

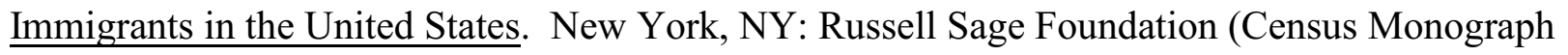
Series).

Jasso, Guillermina and Mark R. Rosenzweig. 1990b. "Self Selection and the Earnings of Immigrants: Comment.” American Economic Review 80:298-304.

Lalonde, Robert J., and Robert H. Topel. 1997. "Economic Impact of International Migration and the Economic Performance of Migrants.” Pp. 799-850 in Mark R. Rosenzweig and Oded Stark (eds), Handbook of Population and Family Economics. Amsterdam: North Holland.

Lee, Jong-Wha, and Robert J. Barro. 2001. "Schooling Quality in a Cross Section of Countries.” Economica 68: 465-488

Martin, Philip. 2004. “Migration.” In Bjorn Lomborg (ed), Global Crises, Global Solutions. Cambridge: Cambridge University Press.

Richardson, Sue and Laurence Lester, "A Comparison of Australian and Canadian Immigration Policies and Labour Market Outcomes," National Institute of Labour Studies, Flinders University, September 2004.

Summers, Robert, and Alan Heston. 1991. "The Penn World Table (Mark 5): An Expanded Set of International Comparisons, 1950-1988.” Quarterly Journal of Economics 106:327-368. 
Figure 1: Schooling Attainment of Employmert Immigrants, by Country

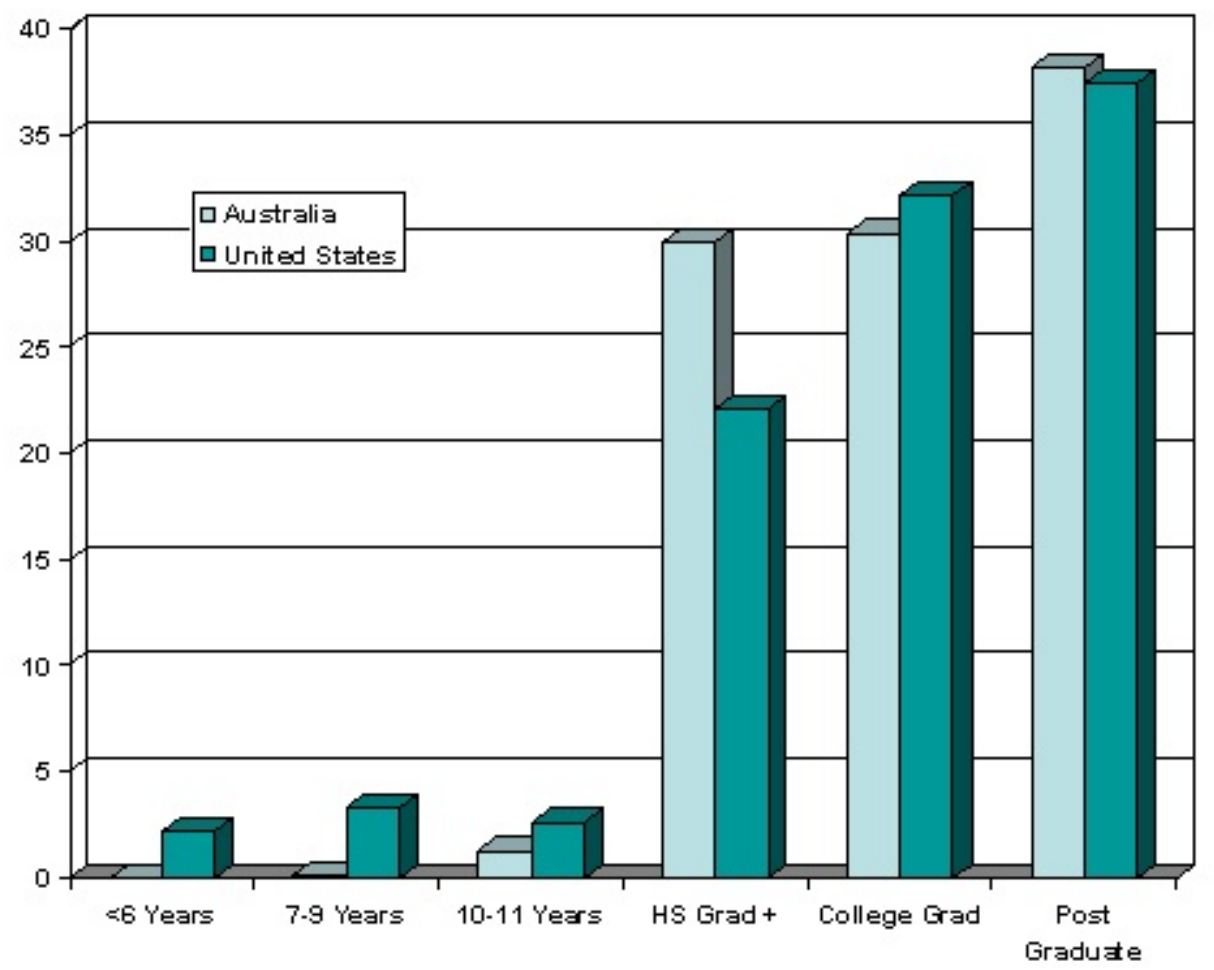


Figure 2: Schoo Ing Attaimerit of Marital munigrants, by Country

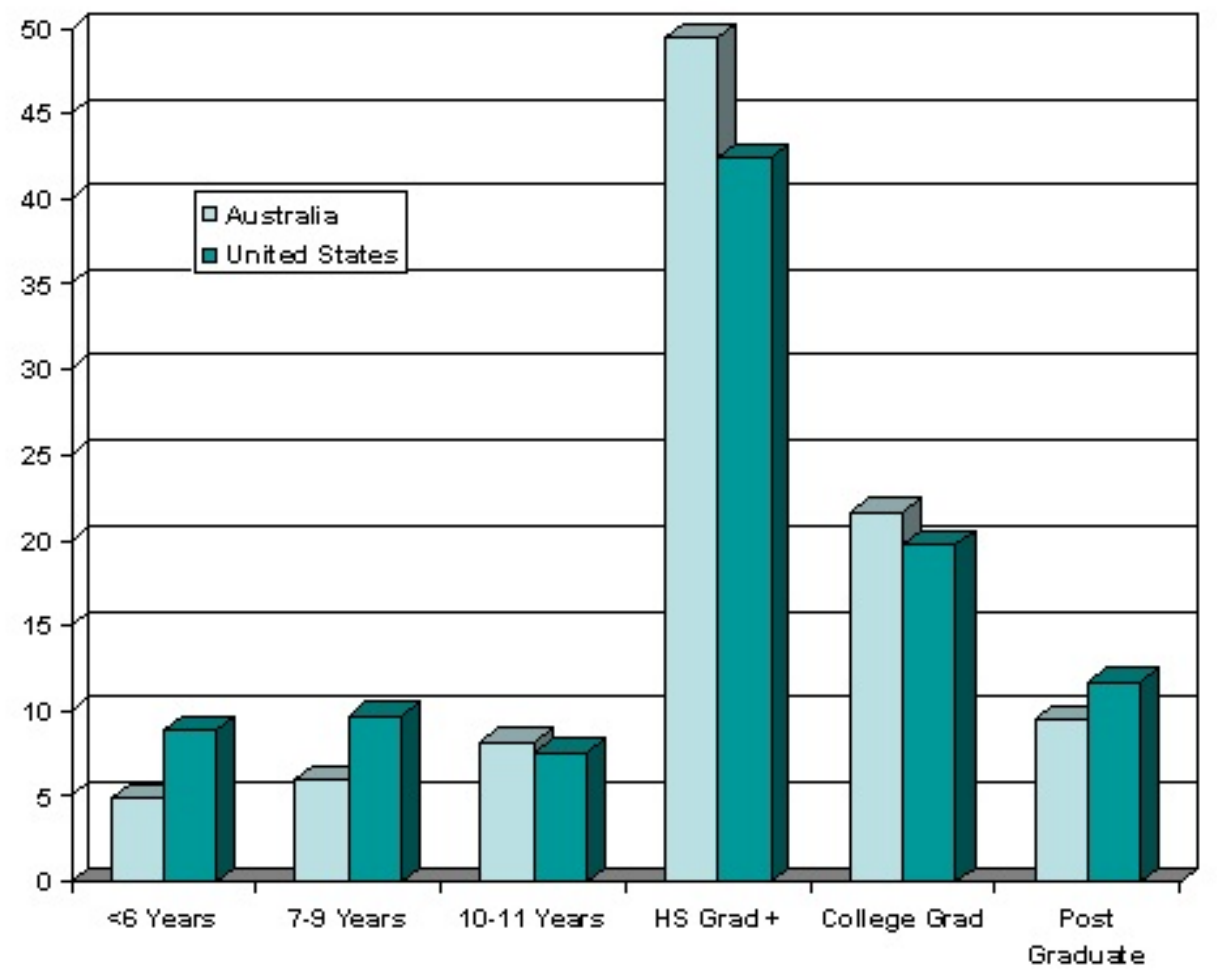


Figure 3: Percent of (New Arrival Immigrants Speaking English Not Well or at All, by Was Category and Country

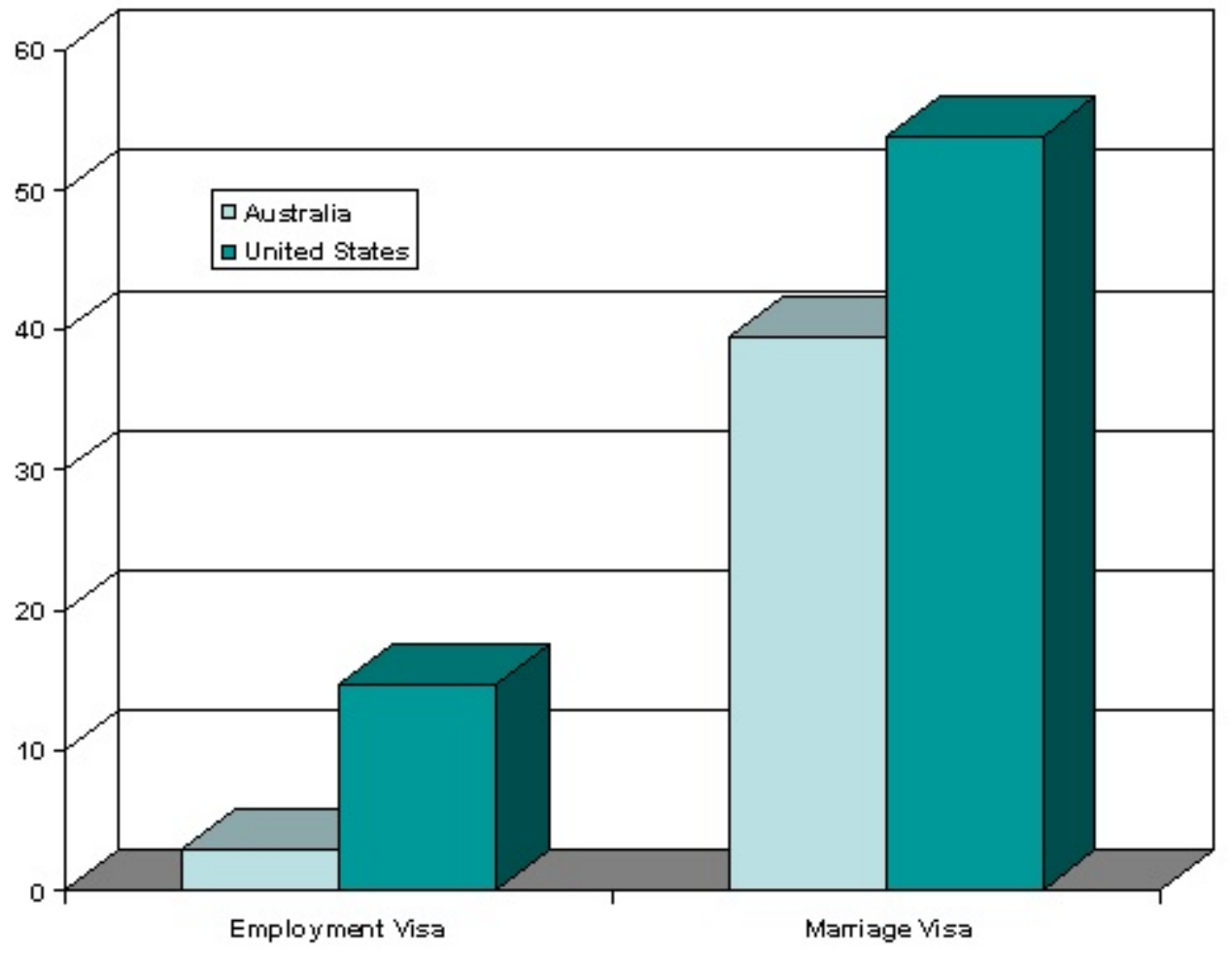


Table 1

ML Blocked Probit Estimates: Determinants of the Probability of Being a U.S. Immigrant

\begin{tabular}{lcc}
\hline Log GDP per worker & -.291 & -.187 \\
Log mean schooling & $(1.42)$ & $(1.02)$ \\
Log GDP per adult-equivalent & .389 & .150 \\
& $(3.20)$ & .230 \\
Distance $\left(\mathrm{x} \mathrm{10}{ }^{-4}\right)$ & .060 & $(1.21)$ \\
& $(0.36)$ & -.258 \\
English an official language & -.259 & $.38 .26)$ \\
& $(5.96)$ & $(2.16)$ \\
Log teacher-pupil ratio, primary schools & .359 & -.137 \\
Log teacher-pupil ratio, secondary schools & $(2.06)$ & $(0.75)$ \\
Constant & - & .968 \\
& & $(3.82)$ \\
Number of countries & - & -3.85 \\
Number of observations (Country populations x $\left.10^{-3}\right)$ & $4,136,943$ & $(2.47)$ \\
Wald $\chi^{2}$ (d.f.) & $147.97(7)$ & 132 \\
Pseudo R & & $4,136,943$ \\
\hline
\end{tabular}

Specification includes dummy variables for missing language, distance and teacher-pupil ratios. Z-statistics in parentheses corrected for clustering of observations within countries. Source for immigrant information: New Immigrant Pilot Survey. 
Table 2

Estimates of the Determinants of the Country Log Skill Price

Based on the Log Wage of U.S. Immigrants Aged 25-59 in their Home Country

\begin{tabular}{|c|c|c|}
\hline Variable & OLS & $\begin{array}{l}\text { OLS with Selection } \\
\text { Correction }\end{array}$ \\
\hline \multicolumn{3}{|l|}{ Country characteristics: } \\
\hline Log GDP per worker & $\begin{array}{c}1.41 \\
(5.01)\end{array}$ & $\begin{array}{c}1.35 \\
(5.21)\end{array}$ \\
\hline Log mean schooling & $\begin{array}{c}-1.77 \\
(3.18)\end{array}$ & $\begin{array}{c}-1.97 \\
(3.23)\end{array}$ \\
\hline Log teacher-pupil ratio, primary schools & $\begin{array}{l}-1.90 \\
(3.68)\end{array}$ & $\begin{array}{c}-2.17 \\
(3.80)\end{array}$ \\
\hline Log teacher-pupil ratio, secondary schools & $\begin{array}{c}1.44 \\
(2.51)\end{array}$ & $\begin{array}{c}1.36 \\
(2.56)\end{array}$ \\
\hline \multicolumn{3}{|l|}{ Immigrant skill characteristics: } \\
\hline Schooling & $\begin{array}{l}.0683 \\
(3.50)\end{array}$ & $\begin{array}{l}.0745 \\
(3.79)\end{array}$ \\
\hline Age & $\begin{array}{l}.0428 \\
(4.32)\end{array}$ & $\begin{array}{l}.0436 \\
(4.50)\end{array}$ \\
\hline Female & $\begin{array}{c}-.169 \\
(1.12)\end{array}$ & $\begin{array}{l}-.123 \\
(0.77)\end{array}$ \\
\hline$\lambda$ & - & $\begin{array}{c}.800 \\
(1.46)\end{array}$ \\
\hline Constant & -1.02 & .713 \\
\hline Number of countries & 54 & 54 \\
\hline Number of immigrants & 332 & 332 \\
\hline F (d.f.,d.f.) & $17.02(10,53)$ & $25.33(11,53)$ \\
\hline $\mathrm{R}^{2}$ & .35 & .36 \\
\hline
\end{tabular}

Specification includes dummy variables for missing country-specific schooling and teacherpupil ratios. t-statistics in parentheses corrected for clustering of observations within countries. Source for immigrant characteristics: New Immigrant Pilot Survey 
Table 3

Top 10 U.S. Immigrant-Sending Countries: Employment Immigrants, 18+

\begin{tabular}{lccc}
\hline Country & Share in Category & Distance (miles) & Estimated Skill Price (\$) \\
\hline India & .252 & 7668 & 12.33 \\
Philippines & .135 & 6964 & 25.64 \\
China & .087 & 5900 & 48.42 \\
Mexico & .052 & 0 & 55.12 \\
Korea & .050 & 5609 & 55.73 \\
United Kingdom & .038 & 3663 & 56.57 \\
Canada & .034 & 0 & 81.1 \\
Taiwan & .023 & 6431 & 227 \\
Brazil & .019 & 4458 & 72.60 \\
South Africa & .017 & 8086 & 39.02 \\
\hline
\end{tabular}

Source: New Immigrant Survey, 2003 Cohort, Round 1

Top 10 Australian Immigrant-Sending Countries: Employment Immigrants, 15+

\begin{tabular}{lccc}
\hline Country & Share in Category & Distance (miles) & Estimated Skill Price (\$) \\
\hline United Kingdom & .209 & 10547 & 56.57 \\
India & .136 & 6430 & 12.33 \\
China & .108 & 5594 & 48.42 \\
South Africa & .088 & 6719 & 39.02 \\
Philippines & .056 & 3905 & 25.64 \\
Malaysia & .039 & 4052 & 123 \\
Pakistan & .034 & 6833 & 60.75 \\
Zimbabwe & .029 & 6944 & 24.45 \\
Fiji & .028 & 2146 & 19.52 \\
Hong Kong & .026 & 4584 & 139 \\
\hline
\end{tabular}

Source: Longitudinal Survey of Immigrants to Australia 2, Wave 1 
Table 4

Top 10 U.S. Immigrant-Sending Countries: Marital Immigrants, 18+

\begin{tabular}{lccc}
\hline Country & Share in Category & Distance (miles) & Estimated Skill Price (\$) \\
\hline Mexico & .237 & 0 & 55.12 \\
Philippines & .048 & 6964 & 25.64 \\
India & .036 & 7668 & 12.33 \\
China & .041 & 5900 & 48.42 \\
Colombia & .033 & 1516 & 35.15 \\
Vietnam & .027 & 7301 & 20.65 \\
Canada & .024 & 0 & 81.1 \\
Peru & .022 & 2620 & 23.22 \\
United Kingdom & .020 & 3663 & 56.57 \\
Japan & .020 & 5134 & 69.55 \\
\hline
\end{tabular}

Source: New Immigrant Survey, 2003 Cohort, Round 1

Top 10 Australian Immigrant-Sending Countries: Marital Immigrants, 15+

\begin{tabular}{lccc}
\hline Country & Share in Category & Distance (miles) & Estimated Skill Price (\$) \\
\hline China & .117 & 5594 & 48.42 \\
United Kingdom & .103 & 10547 & 56.57 \\
Philippines & .071 & 3905 & 25.64 \\
Lebanon & .067 & 8729 & 93.60 \\
Vietnam & .065 & 4809 & 20.65 \\
India & .043 & 6430 & 12.33 \\
United States & .034 & 7572 & 70.50 \\
Iraq & .031 & 8242 &. \\
Malaysia & .029 & 4052 & 123 \\
Fiji & .027 & 2146 & 19.52 \\
\hline
\end{tabular}

Source: Longitudinal Survey of Immigrants to Australia 2, Wave 1 
Table 5

Sending Country Characteristics of Potential and Actual Immigrants, by Visa Type and Receiving Country

\begin{tabular}{|c|c|c|c|c|c|c|}
\hline \multirow[b]{2}{*}{ Rec. Country } & \multicolumn{2}{|c|}{ All Potential Immigrants } & \multicolumn{2}{|c|}{$\begin{array}{l}\text { Top } 10 \text { Countries of } \\
\text { Actual Employment Immigrants }\end{array}$} & \multicolumn{2}{|c|}{$\begin{array}{c}\text { Top } 10 \text { Countries of } \\
\text { Actual Marital Immigrants }\end{array}$} \\
\hline & Mean Distance $^{a}$ & Mean Skill Price ${ }^{\mathrm{b}}$ & Mean Distance ${ }^{c}$ & Mean Skill Price ${ }^{\mathrm{d}}$ & Mean Distance $^{c}$ & Mean Skill Price ${ }^{\mathrm{d}}$ \\
\hline Australia & $\begin{array}{c}7068 \\
(1951)\end{array}$ & $\begin{array}{c}51.8 \\
(58.4)\end{array}$ & $\begin{array}{c}6987 \\
(2589)\end{array}$ & $\begin{array}{c}46.9 \\
(32.0)\end{array}$ & $\begin{array}{c}6559 \\
(2582)\end{array}$ & $\begin{array}{c}50.1 \\
(24.2)\end{array}$ \\
\hline United States & $\begin{array}{c}5903 \\
(1823)\end{array}$ & $\begin{array}{c}61.4 \\
(12.9)\end{array}$ & $\begin{array}{c}6224 \\
(2252)\end{array}$ & $\begin{array}{c}39.1 \\
(44.9)\end{array}$ & $\begin{array}{c}3132 \\
(3405)\end{array}$ & $\begin{array}{c}43.4 \\
(19.2)\end{array}$ \\
\hline
\end{tabular}

${ }^{\mathrm{a}}$ Population-weighted distance of all potential sending countries to the receiving country.

${ }^{b}$ Population- and distance-weighted country skill price across all potential receiving counties.

'Immigrant-weighted distance to receiving country of actual sending countries in immigrant category.

${ }^{\mathrm{d}}$ Immigrant-weighted skill price of actual sending countries in immigrant category.

Sources for immigrant information: Longitudinal Survey of Immigrants to Australia 2, Wave 1 and New Immigrant Survey, 2003

Cohort, Round 1 
Table 6

Determinants of Employment-Visa Immigration by Receiving Country:

Sample Immigrants per Country Population $\left(\mathrm{x} 10^{6}\right)$

\begin{tabular}{lcc}
\hline Variable/Country & Australia & United States \\
\hline Country skill price & -20.9 & -17.3 \\
& $(1.92)$ & $(2.15)$ \\
Distance & -8.55 & -1.22 \\
& $(1.38)$ & $(1.50)$ \\
GDP per adult-equivalent & 3.03 & .290 \\
& $(1.99)$ & $(2.93)$ \\
Population & -.0475 & -.00178 \\
& $(1.43)$ & $(0.58)$ \\
Constant & 75930 & 11659 \\
& $(1.41)$ & $(2.26)$ \\
Number of countries & 132 & .07 \\
$\mathrm{R}^{2}$ & .11 & 132 \\
\hline
\end{tabular}

Absolute values of robust t-statistics in parentheses.

Sources for immigrant characteristics: New Immigrant Survey, 2003 Cohort, Round 1, and Longitudinal Survey of Immigrants to Australia 2, Wave 1. 
Table 7

WLS Estimates: Determinants of the Educational Attainment of Employment-Visa Immigrants in Australia and the United States

\begin{tabular}{lcc}
\hline Variable/Specification & Linear & Log-Log \\
\hline Country skill price & .00406 & .0266 \\
& $(2.55)$ & $(2.45)$ \\
Distance & .000108 & .0172 \\
& $(2.60)$ & $(4.51)$ \\
GDP per adult-equivalent & -.0000213 & -.0169 \\
& $(1.65)$ & $(1.71)$ \\
Population $\left(\times 10^{-3}\right)$ & .00116 & 21.2 \\
& $(4.97)$ & $(5.06)$ \\
Receiving country is the United States & -.454 & -.0250 \\
& $(2.31)$ & 2.43 \\
Constant & $14.99)$ \\
Number of observations & $(40.1)$ & $(21.4)$ \\
$\mathrm{R}^{2}$ & 148 & 148 \\
\hline
\end{tabular}

Absolute values of robust t-statistics in parentheses. Weights are the proportions of sendingcountry immigrants by country.

Sources for immigrant characteristics: New Immigrant Survey, 2003 Cohort, Round 1, and Longitudinal Survey of Immigrants to Australia 2, Wave 1. 